\title{
Post-totalitarian national identity: public memory in Germany and Russia
}

\author{
Benjamin Forest ${ }^{1}$, Juliet Johnson ${ }^{2}$ \& Karen Till $^{3}$ \\ ${ }^{1}$ Department of Geography, Dartmouth College, Hanover, NH 03755, USA; \\ ${ }^{2}$ Department of Political Science, McGill University, Montreal, Quebec H3A \\ 2T7, Canada; ${ }^{3}$ Department of Geography, Royal Holloway, University of \\ London, Egham, Surrey TW20 0EX, UK
}

\begin{abstract}
Through a comparative analysis of Germany and Russia, this paper explores how participation in the memorialization process affects and reflects national identity formation in post-totalitarian societies. These post-totalitarian societies face the common problem of re-presenting their national character as civic and democratic, in great part because their national identities were closely bound to oppressive regimes. Through a comparison of three memorial sites-Sachsenhausen concentration camp memorial in Germany, and Lubianka Square and the Park of Arts in Russia - we argue that even where dramatic reductions in state power and the opening of civil society have occurred, a simple elite-public dichotomy cannot adequately capture the nature of participation in the process of memory reformation. Rather, mutual interactions among multiple publics and elites, differing in kind and intensity across contexts, combine to form a complex pastiche of public memory that both interprets a nation's past and suggests desirable models for its future. The domination of a 'Western' style of memorialization in former East Germany illustrates how even relatively open debates can lead to the exclusion of certain representations of the nation. Nonetheless, Germany has had comparatively vigorous public debates about memorializing its totalitarian periods. In contrast, Russian elite groups have typically circumvented or manipulated participation in the memorialization process, reflecting both a reluctance to deal with Russia's totalitarian past and a emerging national identity less civic and democratic than in Germany.
\end{abstract}

Key words: Germany, monuments and memorials, politics of memory, public memory, Russia.

\section{Introduction}

As much recent scholarship suggests, 'public memory' develops and solidifies through social and cultural processes rather than individual psychology. Societies create 'histories' for themselves through material representations of the past in arenas that, in turn, function as symbols of a 'people' or nation (Halbwachs 1992 [1951]; Nora 1996; Till 2003). Nora, for example, describes how self-consciously constructed commemorative places and events of memory (lieux de mémoire) in modern France, including archives, parades, books and monuments, result from confrontational relationships between official and vernacular 
memories. In that case, alternative, unsanctioned forms of public memory oppose and contest the dominant 'official memories' presented by political elites. We argue that this dichotomy between official (or elite) and vernacular (or public) forms of memory is overly simplistic. Mutual interactions among multiple publics and elites, differing in kind and intensity across contexts, combine to form a complex pastiche of public memory that both interprets a nation's past and suggests desirable models for its future. Through an analysis of two post-totalitarian societies, Germany and Russia, we argue that even where a dramatic reduction in state power and the opening of civil society has occurred, an elite-public dichotomy does not adequately describe the nature of participation in the process of memory re-formation.

Places of memory typically represent the past through historical exhibitions, sculptures or as focal points for commemorative events. They may be symbolic spaces where officials and other social groups express their contemporary political agendas to a larger 'public'. The social and spatial nature of public memory affects both symbolic representations and dominant conceptualizations of the nation. We define public memory as the cultural spaces and processes through which a society understands, interprets and negotiates myths about its past; through those processes, dominant cultural understandings of a 'nation' or 'people' may be formed (Till 1999: 255). Yet there may not be consensus amongst state and local elite groups as to how and if these places should be remade, because 'official' agendas vary. Further, different social groups, functioning as distinct 'publics' and counter-publics, may interact with officials or choose other actions that influence the remaking of these places. As we demonstrate below, public memory is an activity or process rather than an object or outcome. ${ }^{1}$
The process of public memory is especially evident during the political changes that accompany post-totalitarian transitions. A successful transition from totalitarianism to democracy arguably requires a public discussion about how a society remembers its recent past, including how the previous regime repressed civil society through fear, silence and violence. Should such acts be defined as 'crimes'? If so, who is held responsible: individuals, representatives of the state and/or society in general? Such questions are particularly troublesome in societies in transition, especially in those cases where human rights abuses were denied and (may still be) concealed by state officials (Kramer 2001; McAdams 2001). Discussions about 'crimes' and responsibility are central to the politics of public memory, because national histories are (re)narrated through such debates.

For societies undergoing political transition, place-making and memory processes are significant spatial practices through which the national past is reconstructed and through which political and social change may be negotiated. There may be practical reasons for state officials or groups to publicly acknowledge (or forget) victims of the previous regime and communicate post-totalitarian principles: commemoration involves relatively little material investment and does not require most people to change institutional and everyday practices. Yet the memorialization process is far from straightforward. The reasons why a place may be established and (re)situated through commemorations or historical narratives may vary, as will the ways such places of memory will be interpreted and used.

The national and international contexts of public memory in any given society also have profound influences on the negotiation and definition of places of memory. In this respect, Germany and Russia offer striking contrasts. In 
comparison to Russia, Germany has had a long-standing history of addressing and commemorating the crimes and victims of National Socialism through various venues (war tribunals, de-Nazification policies, political education programmes, museums at historic locations, memorials and so on). These attempts were uneven in the divided Germanies following the Second World War and have remained so since unification, resulting from both international coercion and in response to local and national popular protests (Fulbrook 1999; Herf 1997). Although problems, contradictions and silences remain in the postunification process of public memory (Dodds and Allen-Tompson 1994; Smith 2000), Germany has had relatively open and vigorous public debates about its totalitarian periods, including the German Democratic Republic (GDR) past. In contrast, the most powerful Russian elite groups have typically circumvented or manipulated public participation in the memorialization process since 1991, reflecting both a reluctance to deal with Russia's totalitarian past and an emerging national identity less civic and democratic than in Germany.

In this article, we first review the connection between place and public memory, arguing that the specific nature of this relationship is especially important in understanding national identity formation in post-totalitarian regimes. The article then examines three case studies from Germany and Russia. We first consider debates over the renovation of the Sachsenhausen concentration camp memorial in the former GDR. In Russia, we examine placebased memory and forgetting at Lubianka Square (headquarters of the Soviet and now Russian secret police) and the Park of Arts (where several significant Soviet-era statues found new homes after their removal from places of honour in Moscow). We conclude with a discussion of how the nature of participation in public memory is fundamental to the re-presentation of national identity and memory in post-totalitarian societies.

Place, public memory and post-totalitarian societies

What is required for a society to confront a shameful past? Should a new regime memorialize past acts of state-perpetrated violence and injustice as part of its heritage, and if so how? How should the past-the memory of the victims, the acknowledgement of 'crimes', and the confrontation of social responsibility-be represented and remembered? While Germans have long rigorously debated and negotiated such questions as a consequence of the legacies of National Socialism, other states in transition have also begun to explore these difficult questions in recent years.

Central to these public debates have been the processes of defining 'criminal' acts (in state and/or international law) and assigning responsibility for such acts. What is the nature of past acts and under what jurisdiction (cultural, state, international, humanity) should these past acts be tried (if at all)? Questions also emerge about individual and societal complicity, denial and resistance, which become especially complicated when state officials continue to hold positions of power after the political transition. Citizen demands for compensation, accountability and mourning for prior acts of state-perpetrated violence may also be difficult to adjudicate. In short, the larger social task of working through the histories and lingering spectres of these pasts in contemporary society is far from straightforward (Barkan 2000; Buruma 1994; Nevins 2003).

Post-totalitarian societies provide especially 
good cases for studying the negotiation and reformation of public memory precisely because they must face such questions about past regimes. Totalitarian regimes differ from authoritarian regimes in that they demand mass popular mobilization in support of the state, mobilization that ranges from coerced, to indifferently feigned, to genuinely enthusiastic. Even though the extent of actual mobilization may be limited, totalitarian regimes base their legitimacy on symbolic mobilization; even Fascist dictators claimed to rule 'in the name of the people' (Agnew 1998). Thus, as Cohen (1985: 126) observes in regard to the Soviet case, 'historical justice is a powerful "ethical-moral" idea that knows no statute of limitations, especially when reinforced by the sense that the whole nation bore some responsibility for what happened'. Nonetheless, widespread public participation and reckoning with the past did not simply replace top-down state control in either Germany or Russia. Indeed, as we demonstrate, the transitions had complex and ambiguous consequences for public memory in both societies.

If post-totalitarian societies choose to address previous crimes, the process of public memory must reconcile collective and individual participation and complicity in ways that provide both penitence and catharsis. ${ }^{2}$ In such societies, the recognition and acceptance of the past requires public participation for the very reason that the previous regime excluded the 'public'-in the active, democratic and deliberative sense-from state representations of the nation. As a result, dealing with the past after the fall of the regime also demands public participation and attracts interest from citizens in uniquely profound ways. Without genuine involvement by a range of social groups and citizens, representations of the past are simply a new form of state spectacle or propaganda that reinforces centralized authority and ex- cludes democratic participation (cf. Ley and Olds 1988; Thomas 2002). While the politics of place-making and memory in public settings (even in democratic states) is always marked by the spectres of past memorialization practices that served to legitimate state power, ${ }^{3}$ in posttotalitarian societies commemorative genres and representational forms - the monumental memorial on a pedestal, the museum-temple housing national collections and victories, officials ceremoniously laying wreaths on national memorial days-may be interpreted by citizens and others as providing continuity, rather than a break, with state power and social relations. Indeed, continuity may sometimes be a goal of such practices.

In contrast, widespread participation in making and remaking 'public' places of memory can be both a means and an end of post-totalitarian transitions where the past is confronted and a new civic-democratic society is created. Critical discussion about the multiple meanings of the forms, functions and locations of public places of memory, as well as the pasts to be remembered, may be a process through which past injustices can be confronted to work through cultural trauma (LaCapra 1994), and to imagine different futures.

Yet transitions may also result in a crisis of memory and representation, and a questioning of normative 'regimes of place' (McDowell 1999). Societies cannot simply abandon past cultures of memory or meanings of place. Rather, continuities from past to present and familiar narratives of self and belonging frequently appear in the discussions on the constitution of memory in the media, through legal institutions, and local political and cultural practices. We argue that the political and social uncertainties that characterize transitions may in fact encourage a process of bricolage, whereby citizens and social groups use 'a pastiche of materials at hand to create a coherent 
narrative of tradition, memory, and history' (Forest and Johnson 2002: 542). In such cases, it may be especially difficult for a society to confront its recent past, particularly because the recent past remains part of the present, creating unexpected and unknown social instabilities, and making it more difficult for people to imagine possibilities for different futures.

Scholars have identified the 'invention of tradition' as a means to provide stability in a seemingly chaotic present (Hobsbawm and Ranger 1992). Yet they have not been as sensitive to the complex interactions of the range of participants in the process of public memory. Social scientists influenced by Nora (1989) tend to focus on elite roles in public memory formation and reformation, and when they do include citizen participation, they tend to assume implicitly a dichotomy between elite/official memory, on the one hand, and popular/vernacular memory, on the other. For example, in her discussion of concentration camps in German memory, Koonz (1994: 261) distinguishes between official memory (expressed in ceremonies and leaders' speeches) and popular memory (reflected in the media, newspapers, oral histories, memoirs and opinion polls), and argues that 'public memory is the battlefield on which these two compete for hegemony'.

While we agree that there are differences in the outcomes of public memory, the emphasis on this official/popular dichotomy results in an incomplete understanding of the process of memory. Certainly there are methodological reasons for emphasizing official memory, including the limited nature of archival materials and documents, and the investment of time needed to research contemporary transitions. Nonetheless, the epistemological assumptions underlying the official/popular memory dichotomy also inform how scholars read such documents and practices, and interpret power relations. Koonz, for example, while providing a rich range of representational materials in her analysis, problematically assumes that ceremonial speeches reflect the intentions of those in power, and that newspaper articles represent the populace. Such an approach implies that elites constitute a coherent group or that they can impose their ideological understandings on to seemingly passive subjects through grandiose public displays and monumental spaces. While this may be true in certain ways and for certain forms of control, power cannot be conceived merely as a directional flow of ruler to ruled, or described simply as repression and domination (Foucault 1977a). Particularly in democratic or quasi-democratic settings, elites may need to negotiate with diverse centres of power, or may need to respond to popular understandings and interpretations. Even in totalitarian and authoritarian regimes, individuals may choose to resist elite interpretations of monumental landscapes through everyday practices, such as telling jokes (Atkinson and Cosgrove 1998; Hershkovitz 1993; Scott 1985).

At the same time, recent work maintains the distinction between official and popular memory by assuming a crisis model of modern society, nostalgic understandings of the premodern and/or romantic depictions of political struggle (Johnson 1999; Legg 2004; Sturken 1997; Till 2003). Nora, for example, describes the disappearance of 'true' memory-embodied in cultural practices situated in milieux, or contexts, of memory-with the rise of history-self-reflexive acts of archiving and ceremoniously re-enacting the past-through the emergence of modern lieux, or sites, of memory (Nora 1989, 1996). As Legg (2004) argues, Nora's nostalgia for a time when memory was 'real' prevents him from critically engaging with the contesting and heterogeneous claimants to the idea of the French nation. Nora's project, continues Legg, mourns for the French nation, or at least the ideal of a time 
with coherent state power as opposed to a pluralistic nationhood. Further, Johnson (1999) argues that Nora's temporal framework treats space as epiphenomenal to the process of history.

Scholars who take seriously the 'voices from below' and what Foucault (1980) called 'subjugated knowledges' into the analysis of memory practices tend to focus on acts of resistance and the creation of 'alternative' places of memory in ways that also maintain the official and popular memory distinction (Bal, Crewe and Spitzer 1999; Davis and Starn 1989; Gillis 1994a). Gillis (1994b) delineates a historical progression from pre-national to national to post-national phases of commemoration, where in the final phase, social groups challenging elite and official depictions of national history have severed the ideological coherence between the nation and the state. Within this postmodern phase of commemoration, scholars often theorize alternative sites of memory as venues of resistance that challenge exclusive and totalizing national narratives, such as Young's (1993) counter-sites of memory by German artists. Such alternative places are theorized, following Foucault (1977b), as popular sites of 'countermemory' defined in terms of their challenge to official and elite commemorative practices.

This analytical emphasis on resistance and opposition simplifies the agendas of various individuals and groups who may, at times, work together to create alternative or subaltern venues of memory (Frazier 1999). Following Pile (1997) we argue that the underlying assumptions about the domination-resistance coupling are questionable (cf. Abu-Lughod 1990; Sharp, Routledge, Philo and Paddison 2000). Social groups historically have interacted with officials to establish state venues of memory; officials and elites may also play significant roles in the constitution of alternative places.
Further, as Sturken (1997) demonstrates, not all places that result from this entangled process of memory are necessarily political, and warns of the implicit romanticization of Foucault's conception of popular memory.

Ultimately, the elite-public dichotomy is limiting because neither category is conceptually or politically coherent. Local, national and even international officials, politicians and other elites may have very different ideas of what places of memory mean, what forms they should take, what pasts should be remembered (and in whose name) and what symbolic meanings these places should communicate to a larger audience (other officials, locals, nationals or tourists). They may have different agendas for these places, and may compete with each other for control over monument sites, leading to ideological conflict or incoherence (Agnew 1998; Forest and Johnson 2002).

Likewise, there is seldom a coherent 'public' or populace. Rather, there are many publics, sub-publics and counter-publics, each possessing distinct political agendas, access to resources and authority, and understandings of place (Fraser 1990). Their conceptualizations, uses, experiences and understandings of specific places of memory may differ sharply depending upon their social positions and needs in the present and projected future. As the case studies below demonstrate, at certain moments some publics enjoy greater support, resources and access to authority than others, and thus may actively change landscapes; at other times these publics are excluded (by state officials, the media or other actors) in various realms (Staeheli 1997). Further, while some publics may engage in passionate conflicts with local and national authorities over the politics of memory, in other circumstances many people are simply indifferent to these monumental conflicts.

In short, public memory is a political process 
that both creates and responds to power relations and identities. At the national scale, elites, publics and public spheres are dynamic, multiple, and intersecting social and spatial categories that cut across and through local, urban, regional and international affiliations and power relations. Consequently, studies of public memory require nuanced understandings of the complex relationships among these unstable categories and social groupings that are continuously created and recreated through placemaking, social memory, and their related multi-scaled and shifting configurations of identity and belonging.

\section{Place and public memory in Germany}

Unlike other countries undergoing the transition from East Bloc satellite state to Western democracy, in Germany the history of the GDR is linked to the history of Germany's other totalitarian state, the Third Reich. Indeed, the very existence of the GDR was a direct legacy of National Socialism; after the end of the Second World War, Germany and Berlin were partitioned and occupied, and later divided into two states that came to symbolize a larger Cold War conflict. Not only did the National Socialist past continue to haunt the new Germany, so too did the ways that the past was remembered and forgotten in the Cold War period (Herf 1997). These hauntings were materialized in the 'New Berlin' and Germany through the establishment of new places of memory and the remaking of GDR commemorative sites, including sites of National Socialist violence (Habermas 1997; Huyssen 1997; Till forthcoming).

Contemporary German discussions about the GDR totalitarian past were unique in another way: they were tied to Western narratives about 'winning' the Cold War, of 'good' tri- umphing over 'evil'. No other state so directly addressed Cold War narratives of victory while simultaneously working through a totalitarian past. Following unification, the workings of the GDR regime were interrogated through legal trials of leaders and border police, and federal investigative commissions, a process based in part on Germany's experience dealing with the National Socialist past (Deutscher Bundestag 1994). This process included scholarly research and discussions over which public places of memory in the former East should be closed, reformed or left open. Nonetheless, a relatively black-and-white representation of the GDR regime emerged to replace more nuanced understandings of East German society that had been prevalent for the previous twenty years (Fulbrook 1997). 'The new historical picture which was presented was one of heroes, villains, and victims: of an evil gang of criminals at the top oppressing an innocent people below, challenged only by a few resourceful heroes of the opposition' (Fulbrook 1999: 226).

The post-unification narrative of East German society drew from the familiar trope of 'Germans as victims', one dating back to the 1930s, if not earlier, that projects responsibility for past actions on to an ill-defined evil other (Assmann and Frevert 1999; Marcuse 2001). In this new myth, 'ordinary' East Germans were represented as 'victims' of repressive regimes and not held personally responsible for their actions (and inactions) supporting the status quo. Dominant cultural narratives also represented the Federal Republic of Germany (FRG) as the 'natural' and inevitable model for a unified German democratic state. Although the German constitutional mandate required it, there was no renegotiation of the Federal Republic's Basic Law (similar to a constitution) at the moment of German reunification. Based in part on this omission, Habermas (1997) argues that post-1990 social memory did not reflect a 
self-critical re-evaluation of the West German state and political system.

Western mainstream magazines such as Der Spiegel, newspapers like the Frankfurter Allgemeine Zeitung and commentaries by former Chancellor Kohl sent the message that East Germans needed to work through their pasts in order to become part of (West) German civil society. A problematic understanding that the 'West' had overcome its National Socialist past and established a 'normal' democracy was implicit in this narrative. The numerous radical right activities that included xenophobic acts, brutal attacks and even murder in places like Rostock and Solingen were represented as an East German youth problem. Yet evidence indicated a more complicated social situation, such as the activism and support of the radical right in Western states (including activities by socalled 'necktie neo-Nazis') and by West German voters who supported far right or established conservative parties running on anti-foreigner campaigns. Rather than examine this violence within the shifting social contexts of unification, West German experts and criminologists characterized former GDR citizens as morally flawed (Hörschelmann 2001).

Places of memory, their historical narratives and their social functions offer venues to explore how (and if) post-unification German identities changed. Some scholars have examined the material erasure and reinterpretation of GDR landscapes of memory in Berlin where numerous monuments were quickly torn down, Marxist-Leninist institutions were closed and street names previously dedicated to communist fighters changed back to their pre-1933 names (Azaryahu 1997; De Soto 1996; Till 1996). Activist Western-based groups, such as the Active Museum of Resistance against Fascism in Berlin, argued that getting rid of the GDR past in the material landscape recalled the 'forgetting' of the National Socialist past after the war, and would only make coming to terms with the GDR past more difficult for future generations (Aktives Museum 1990), (Till, personal interviews with Christiana Hoss and Martin Becher, Active Museum academic staff, Berlin, 1997). Yet memorials created by the East German state located at sites of National Socialist violence could not simply be shut down. Instead, these places of memory were renovated and their histories revised to reflect Western standards of pedagogy and historical research.

The Sachsenhausen Concentration Camp Memorial Museum in Oranienburg, Brandenburg (near Berlin) in the former GDR was one such place where post-totalitarian social identities were both constituted and challenged (Figure 1). A range of actors have articulated and debated questions of social responsibility for the dark national past through the functions, forms and public meanings of this memorial. Certain aspects of this process have been troubling: the continued hegemony of conservative cultural narratives, such as Germans as 'victims'; the dominance of Western expert opinion; and the simultaneous lack of critical reflection about Western practices of memory. Nonetheless, we interpret the discussions about Sachsenhausen as a positive result of a longstanding, albeit conflict-ridden, post-war West German politics of memory.

Sachsenhausen was originally built as a 'model' concentration camp in 1936 and included a SS-training camp and related labour camps; during the GDR period some of these buildings were reused by the People's Army and later the GDR police. ${ }^{4}$ Before this time, from 1945 to 1950, Soviet occupiers used Sachsenhausen (like Buchenwald) as a 'Special Camp' to intern Nazi functionaries as well as perceived enemies of the Soviet and emerging GDR states. For ideological reasons, that history of the camp was not officially documented 


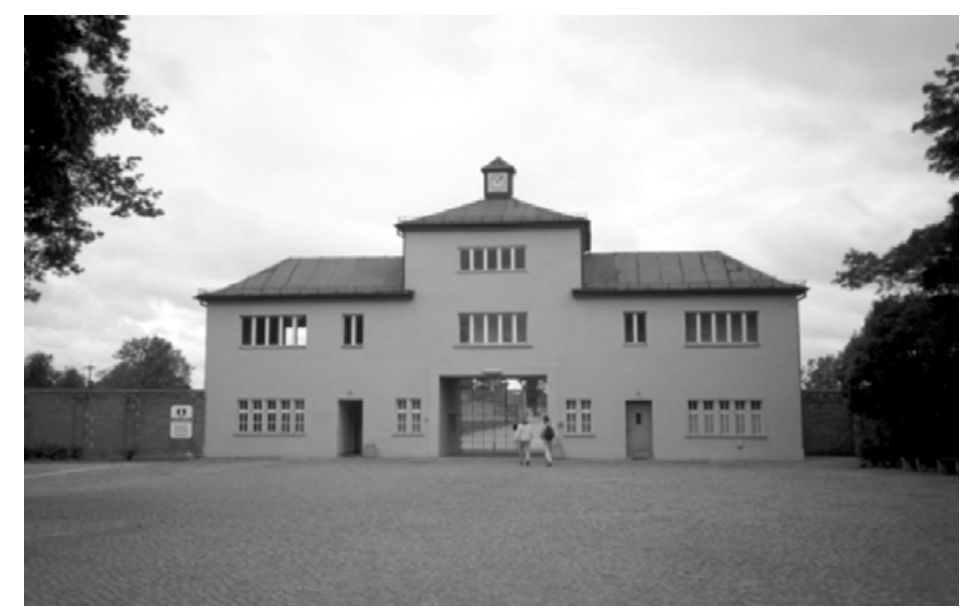

Figure 1 The main gate of Sachsenhausen's prisoner concentration camp, Oranienburg, August 1997. Photograph by K. Till.

in the GDR. In 1961, in response to National Socialist camp survivors' demands, a memorial complex was built, and Sachsenhausen, together with Buchenwald (1958) and Ravensbruck (1959) concentration camp memorials, was transformed into one of the central commemorative ritual sites of the GDR. A monument, museums and ceremonial events commemorated international anti-fascist resistance fighters to support the myth of the East German state (Morsch 1996, 2001; Wiedmer 1999; Young 1993).

After unification, the new, Western directors of Sachsenhausen faced the difficult task of transforming this central symbol of East German anti-fascist identity into a part of larger national and international networks of historical memory. They used recommendations from a committee of historians and memorial museum experts commissioned by the state of Brandenburg to evaluate these GDR concentration camps (Endlich 1992). According to the expert commission's findings, the racist underpinnings of National Socialist persecution were ignored because the historical exhibitions at Sachsenhausen created during the GDR emphasized the central role of communist prisoners (including GDR leaders) in anti-fascist resistance. Camp histories emphasized the international origins of camp prisoners (from 19 different countries) and their heroic struggle against Fascism, rather than describe the reasons why Jews, Sinti and Roma, and other social groups, such as homosexuals, were selected for genocide or persecution (Deutscher Bundestag 1994; Endlich 1992; Morsch 1996). An immediate goal of the new directors, therefore, was to work with National Socialist prisoner and survivor groups whose histories had been underrepresented or misrepresented during the GDR (Till, personal interviews with Günter Morsch, Oranienburg, 1997).

The emergence of new victim groups complicated this goal. Following unification, human remains and mass graves were discovered at the Soviet internment 'Special Camps' at Sachsenhausen and Buchenwald. Directors had to address the concerns of newly formed Soviet 
internment camp survivors and victim groups who demanded recognition of their suffering and who received local media attention. According to museum directors, considerable tension among different victim groups emerged. ${ }^{5}$ Indeed, at times these groups refused to sit on the same memorial advisory and consulting boards because National Socialist survivor and prisoner groups felt that the internment camp groups equated their suffering with National Socialist persecution.

The new directors pursued a 'decentralized approach' to reinterpret the artifacts, historical research and memorialization of the GDR period, and to provide a more extensive representation of the camp's history under National Socialism and for the periods after 1945 (Till, personal interviews with director Günter Morsch, Oranienburg, 1997, 2000). Directors hoped to emphasize the historical significance of the camp during National Socialism, but also to include the post-war histories in new exhibits. The decentralized approach does two things: it offers exhibitions about different aspects of the camp's historical layers at particular sites and designates specific areas for commemorative and mourning activities by different victim and survivor groups at different times of the year (Till, personal interviews with Günter Morsch, Oranienburg, 1997, 1999, 2000) (also see Morsch 2001). This decentralized approach draws from the grassroots history workshop and memorial museum movements that developed in the FRG in the 1980s (Rürup 2003; Till 1996), although new historical research conducted after unification has also had an influence. This approach, however, conflicts with commonly accepted East German, and to a lesser degree West German, understandings of concentration camp memorials before unification. Memorials in both the FRG and GDR were generally understood as places of memory for National Socialist vic- tims, and in the case of the GDR, for resistance fighters. In the case of Sachsenhausen this meant that only the triangular portion of the concentration camp proper was preserved as a historical site. When new directors proposed including the SS training camp, SS officer residential units and inmate labour camps as part of the concentration camp memorial complex, a number of controversies ensued.

First, the proposal to expand the memorial conflicted with local plans to urbanize some of the same area. In 1992-3, the City of Oranienburg (near the camp site) sought to develop an area that included the locations of the former SS troop camp and SS officer residences (Stadt Oranienburg 1992). The winning design of the public competition proposed a multi-use complex with residential units, office space, schools and a sport centre (Berliner Morgenpost 1993; Der Tagesspiegel 1993; Stadt Oranienburg 1992). Although the proposal encouraged the integration, rather than isolation, of the historic area and the contemporary city, camp directors and other West German memory experts objected, arguing that this was a 'profanization' of an important national historical site. ${ }^{6}$ Oranienburg city officials were initially confused about the intense criticisms and debates, but subsequently rescinded their initial decision and selected a proposal by Daniel Libeskind that had been awarded honourable mention in the competition. Libeskind's plan, called 'Hope Incision', rejected the premise of urbanization, and called for a confrontation with the past through excavations, signs and landscape designs that mark historic buildings and significant sites (Forschungsgruppe Stadt WDorf and Schäfer 1994; Libeskind 1993; Stadt Oranienburg 1993: 63). These historical sites provide a dialogue with contemporary land uses such as schools, an international youth centre, an Institute for Tolerance and an Institute for Human Rights. 
These debates included more than historians, urban professionals and artists. Local residents living in former SS officer neighbourhoods during the GDR formed a citizen's initiative opposing preservation status of their homes. They wanted to prevent what they felt was the 'Western' usurpation of their newly acquired property rights, but also feared that their neighbourhood would become a neo-Nazi pilgrimage site (Till, personal interview with citizen initiative organizer, Oranienburg, 1997). ${ }^{7}$ In negotiating the conflicts between Western historians and local East German citizens, the Libeskind architectural group became very important. Through discussions with the architects in formal and informal venues (including local pubs and coffee shops), local residents finally agreed to place their homes under 'group' historical preservation provisions, which will limit the changes they can make to those structures, but still allow the Libeskind project to be realized (Till, personal interview with Mattias Reese, project co-ordinator, Daniel Libeskind Buro, Berlin, 1998).

Although West German directors and memorial museum experts, and American-West German architectural teams played an influential role in these public debates, the reconceptualization of Sachsenhausen resulted from a complex process of negotiation among many actors with different personal and political interests in the future of this site, including representatives of various social victim and survivor groups; memorial advisory boards, educators, historians, politicians and memorial museum directors; homeowners' citizen group initiatives; historic preservationists; city officials; city planners; architects; and others. Debates largely arose in response to memorial preservation proposals, planning competitions, media coverage about historical and archaeological findings, citizen initiatives and other related contemporary events. Although some
GDR citizens had practical reasons for their involvement, many attended planning boards and open meetings, discussed plans with architects and preservationists, and were active and influential in victim and survivor groups. Indeed, one organizer of a homeowner citizen initiative group now volunteers at Sachsenhausen's main office. By confronting the complex histories and perspectives of Sachsenhausen as a historical place, the groups involved found ways to begin working through post-totalitarian histories as well as GermanGerman post-war identities.

\section{Place and public memory in Russia}

Like Germany, Russia faced an internal debate about its totalitarian past after the fall of the communist regime. While repression and human rights violations had characterized the Soviet regime throughout its history, this debate cut most deeply in regard to the Stalin era and the secret police. Under Josef Stalin, who ruled the Soviet Union from the late 1920s until his death in 1953, millions of Soviet citizens were executed, exiled to labour camps, or otherwise disgraced and traumatized (Conquest 1973; Tucker 1990). Millions more denounced their fellow citizens out of fear or desire for advancement. The state security services, then known as the NKVD and already familiar with the instruments of repression, carried out this political persecution.

Although the Communist Party distanced itself from much of this legacy during the Khrushchev-era de-Stalinization campaign (when, for example, Stalin's body was removed from the Lenin Mausoleum), this selective rewriting of history occurred without significant public participation. The 'excesses' of the regime were blamed on Stalin as an individual, even as his bloody efforts to collectivize and 
industrialize Russia were tacitly approved (Cohen 1985; Khrushchev 1956). Moreover, the communist representations of Stalinist history did not lead to significant change in the secret police apparatus (by then renamed the KGB), which merely scaled back its intimidating activities (Knight 1988). Under Brezhnev the crimes of the Stalin era were once again swept under the rug, not to surface again until Mikhail Gorbachev introduced glasnost in the 1980s (Tumarkin 1994).

Gorbachev signalled his willingness to address the past by releasing physicist and activist Andrei Sakharov from exile in Gorky, encouraging the 'rehabilitation' of individuals exiled or murdered in the Stalin era, and in general opening up Soviet history to public discussion and evaluation. Human rights groups emerged at this time as well. The most important of these, Memorial, aimed to reveal and acknowledge the dark past by (among other efforts) erecting a national monument to victims of political repression (Smith 1996). However, this movement of memory angered those who viewed the overall contributions of Stalin and the secret police in a more positive light (Andreeva 1990 [1988]; Ligachev 1993). It is not coincidental, for example, that the heads of the KGB and the Ministry of the Interior played prominent roles in the failed attempt to overthrow Gorbachev in August 1991 (Daniels 1993). These controversial and painful debates about the past contributed to the collapse of the Soviet regime. When the Russian Federation then emerged as an independent state, for the first time Russians as a nation had to think about incorporating and recognizing this aspect of Soviet history in their public memory.

Unlike in Germany, though, the question in Russia was not how to recognize and memorialize the totalitarian past, but whether it should be openly acknowledged as a problem at all (Applebaum 1997; Kramer 2001; Weir 2002). In
Russia, no majority understanding emerged that saw such public remembering as necessary for the future health of the state (Suny 1999). Many Russian political elites had held high positions in the Soviet party and state apparatus, and often this translated into a desire to downplay or simply 'move past' the past. Similarly, much of the population did not see the past, on balance, as something to be ashamed of, or believed that energy and resources should be invested in public displays of repentance. For example, a survey by the respected agency VTsIOM found in early 2003 that over half of Russians polled viewed Stalin's role in Soviet history as 'probably' or 'definitely' positive (VTsIOM Analytic Agency 2003). Indeed, the New Russian Barometer surveys sponsored by the Centre for Public Policy at the University of Strathclyde since 1993 consistently show that large majorities of Russians rate the pre-perestroika political and economic systems much more highly than the current ones (Rose 2002). Moreover, unlike Germany, Russia was not joining a 'West' whose political discourse demanded a reckoning with the past. As a result, unlike Germany's Neue Wache memorial, Russia as yet has no recognized central national monument to the victims of political repression.

As in Germany, conflict over memory in Russia cannot be described as an elite-public battle. Rather, debate embraces majority elites and publics who prefer to forget, and minority elites and publics who fight to remember. In most cases, however, the process of public memory cannot be described as one of negotiation and compromise. In the typical pattern, leading political elites erect and remove monuments with little effective outside input (Forest and Johnson 2002). If minority elites and public groups mobilize to oppose these efforts, majority elites listen but rarely reverse their decisions; only reactions from other politically 


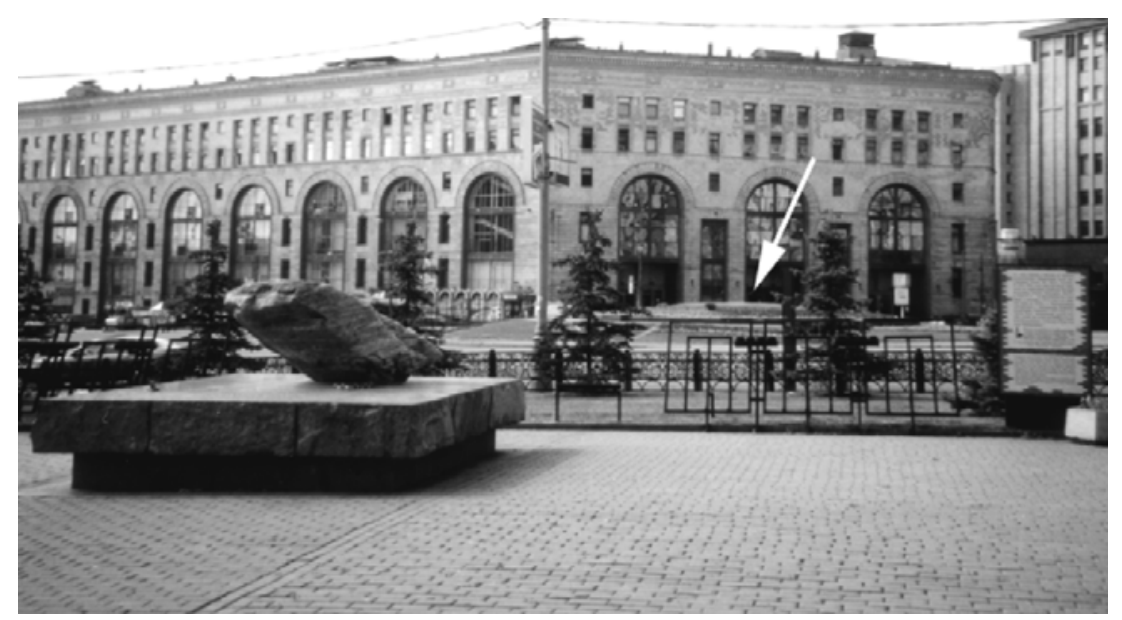

Figure 2 Lubianka Square, Moscow, August 2001. The Solovetskii stone is on the left. The arrow indicates the former location of Dzerzhinskii's statue in the centre of the square. Photograph by B. Forest and J. Johnson.

powerful forces prove effective. ${ }^{8}$ If the minority opposition is loud enough, majority elites may 'mobilize' broader public opinion in their favour through commissions, polls and proposed referenda, using these tools to justify their actions. In addition, particularly in terms of elites, 'majority' and 'minority' can refer not simply to numbers, but to power resources. With former security services head Vladimir Putin as president, for example, Russian elite groups wishing to reinterpret the past in a more positive light now have a supporter at the top. As the case studies of Lubianka Square and the Park of Arts reveal, the battle over whether and how to remember the past in Russia remains sensitive and complex, yet far more circumscribed than that in Germany.

\section{Lubianka Square}

The changing face of Lubianka Square in Moscow epitomizes Russia's conundrums over recognizing its totalitarian past (Figure 2). This is a tale of three monuments-one old, one new and one not yet constructed-and the imposing headquarters of the state security service looming over it all. The first monument, to Soviet secret police founder Feliks Dzerzhinskii, stood in the centre of the square until 1991. Since its removal, different elite groups have made three efforts to restore it. The activist organization Memorial installed the second monument, a small stone from the Solovki gulag, in a park on the square's edge in 1990. The third, a proposed central national monument to victims of political repression, has never been erected despite Memorial's continued fundraising and lobbying efforts.

For Russians, Dzerzhinskii symbolizes the order, the terror and the power of the Soviet regime. In August 1991, after the failed coup attempt, crowds surrounded the monument and tried to tear it down. The Moscow city government, riding the populist wave, acquired a crane and removed it (Luzhkov 1996). After- 
wards, as disillusionment with the Russian political, economic and social situation set in, the empty circle of grass where Dzerzhinskii's monument had stood became a festering sore in the heart of Moscow. During the 1990s, the conflict over the restoration of Dzerzhinskiiand thus, symbolically, the Soviet past-was a conflict fought principally among elites. In December 1998, the State Duma (Russia's lower legislative house) overwhelmingly passed a resolution to restore the statue 'as a symbol of the fight against crime’. The Agrarian Party, Communist Party and several smaller parties supported the resolution, while only Yabloko (the party of liberal, educated urban intellectuals) opposed it unanimously (Tolstikhina 1998). Moscow mayor Yurii Luzhkov forcefully rejected the resolution, but on the grounds that it violated the principle of local control. The Agrarians and Communists proposed a similar resolution in the State Duma in July 2000, but this time could not muster enough votes to pass it (Uzelac 2000).

This dynamic changed again in the years after Putin's election in 2000, as the president symbolically and rhetorically re-interpreted the place of the security services and the Stalinist past in a more positive light (Forest and Johnson 2002; Kurilla 2002; Traynor 2000). At the same time, Putin made strong efforts to re-consolidate political power in the hands of the presidency while taming both the Duma and assertive local leaders like Luzhkov. As a result, Luzhkov reversed his position on the Dzerzhinskii question. When Nikolai Patrushev, head of the FSB (the KGB's successor and current occupant of the Lubianka), publicly said in September 2002 that he would like to see Dzerzhinskii back in his former place of honour, Luzhkov apparently interpreted it as a hint from Putin (Abdullaev 2002). Attempting to curry favour with the powerful president, Luzhkov stated that Dzerzhinskii's statue was an 'excellent monument' and that it should be returned to the square (Filimonova 2002).

While the Communist Party, the FSB and their supporters cheered Luzhkov's proposal, liberal parties and human rights groups protested (Abdullaev 2002). The Union of Right Forces party proposed a Duma resolution condemning the idea, which failed for lack of a quorum. Liberal political elites joined human rights groups for a small protest demonstration on Lubianka Square, and circulated a petition against the move (Associated Press 2002). Memorial re-released its 1998 statement against restoration, but admitted in the new preface that restoring the statue 'is supported by influential forces at the top of Russia's political power structure' (Memorial 2002). Despite the opposition from minority parties and human rights groups, a reliable nationwide poll revealed that Russian public opinion favoured Luzhkov's proposal, with 56 per cent supporting Dzerzhinskii's restoration, 30 per cent not expressing an opinion and only 14 per cent speaking out against it (Public Opinion Foundation 2002). ${ }^{9}$

Throughout the debate, Putin himself remained silent on the matter. As Sakharov Foundation director Yurii Samodurov observed, 'We cannot imagine the German chancellor not protesting if the mayor of Berlin decided to erect a monument to the head of the Gestapo. Here, it is possible' (quoted in Rodin 2002). ${ }^{10}$ However, an official statement from the Kremlin did come four days after Luzhkov's proposal, when deputy chief of staff Vladislav Surkov attempted to defuse the tension by stating that 'today, some are calling for the restoration of the Dzerzhinskii statue; tomorrow others will demand the removal of Lenin's body from the mausoleum ... both [ideas] are equally inopportune' (quoted in Birch 2002). As a result, in January 2003 the Moscow City Council finally rejected 
Luzhkov's proposal to restore the statue, on the grounds that it would cause unnecessary discord (O'Flynn 2003). The centre of the square thus remained empty, its fate (like that of the monument itself) still unresolved.

Given this significant, near-successful effort to restore a central symbol of the totalitarian past, the second monument on Lubianka Square-the Solovetskii stone-seems eversmaller and more incongruous. As its inscription states, 'The society "Memorial" was especially nominated to provide this stone from the territory of the Solovetskii camp and to erect it in memory of the millions of victims of the totalitarian regime'. Memorial placed this monument in October 1990 with the express co-operation of the Gorbachev regime and the Moscow city government, at a moment when a few powerful elites preferred to remember the Soviet past in order to transcend it. For almost a year, Dzerzhinskii's statue and the Solovetskii stone stood across the street from each other, as duelling symbols of a state tearing itself apart. After Dzerzhinskii's removal, its location served as a rallying point for anti-communist protestors and victims of the Stalinist regime.

Its presence, however, is also a constant reminder of the absence of a third monument, a proposed national monument to the regime's victims. Memorial has laboured almost alone in this seemingly lost cause to construct a central symbol of memory and atonement. This lengthy, so-far futile effort to construct a central monument contrasts sharply with the rapid construction of a prominent state-sponsored monument to those who died at Moscow's Dubrovka theatre in October 2002 during a hostage crisis perpetrated by armed Chechen separatists. Just one year after the attack, Putin presided over the well-publicized unveiling of a large monument commemorating the victims (Yablokova and Valueva 2003). As Memorial's website ruefully observes:
Up until now, even after many discussions and two design competitions, Memorial has not received a conclusive answer to the question of whether or not the monument will be established. Or has the Solovetskii stone... already become this monument?... The work of recent years demonstrates that the perpetuation of memory exceeds the powers of one social organization. (Memorial 2002)

In short, following Memorial's placement of the Solovetskii stone in 1990 and the removal of Dzerzhinskii's statue in 1991, the transformation of Lubianka Square arguably represented the greatest success in recognizing victims of the Soviet state. Yet even this success was ambiguous, both because of the resistance (and apathy) faced by Memorial in its efforts to construct a central monument to the victims of Stalinist repression, and because of subsequent attempts to return Dzerzhinskii to his pedestal. As the conflicts over Lubianka Square demonstrate, many Russian elites and publics would not only prefer to forget the injustices of the past, but to symbolically restore their perpetrators to a place of honour.

\section{The Park of Arts}

On the evening of 22 August 1991, the Moscow city government used cranes to remove the statues of Dzerzhinskii and other Soviet leaders from their pedestals in the centre of Moscow. These statues ended up in the Park of Arts (sometimes also referred to as 'The Park of Totalitarian Art'). Subsequently, the park came to play an unusual role in the re-conceptualization of public memory. Not only did local political elites engage in a concerted effort to de-politicize the statues, but Yurii Luzhkov also approved the erection of an immense and reviled statue to Peter the Great on the riverbank by the park's edge. Local elites carried 
out both the de-politicization of the Soviet statues and the construction of Peter the Great with little public input (Forest and Johnson 2002). Yet several public groups actively (and futilely) protested against the statue of Peter the Great, while the de-politicization strategy met resistance only from Dzerzhinskii's supporters.

At first, the Soviet statues sat forlorn and unmarked in a weedy corner of the park. But in 1996, the Moscow city government formalized the display by restoring the statues, installing small plaques identifying the figures, and naming the area the Park of Arts. The new park was placed under the jurisdiction of Muzeon, a subsidiary of Moscow's Committee on Culture, and became a display area for contemporary artistic works. By the summer of 1999, former Soviet leaders shared the park with a rose garden, abstract religious art and numerous busts.

The most important Soviet-era statues had plaques describing the subject, artist, material used and where the piece had been displayed. After this description, the plaques attached to the statues ended with a depoliticizing disclaimer: 'It has historical and artistic value. The monument is in the memorializing style of political-ideological designs of the Soviet period. Protected by the state'. Characterizing these statues in historical and artistic terms intended to drain them of contemporary political significance by politically decontextualizing the works and emphasizing their alleged artistic value. Indeed, the pieces were placed haphazardly and the descriptions never referred to more than a single statue.

Only the display surrounding Stalin's statue had obvious political symbolism, and it is clearly an unusual case. Unlike the other, recently removed Soviet-era statues, the Stalin statue was a casualty of the de-Stalinization process under Khrushchev, and had reportedly been buried in the sculptor's garden until it was 'resuscitated' and placed in the park in 1991 (Boym 2001). Ironically, the Stalin statue thus reappeared at the same moment that his leadership was most severely called into question. Then, at the height of Luzhkov's anti-communist sentiments in 1998, the amateur artist Evgenii Chubarov donated a sculpture group symbolizing the gulag to the park, which promptly erected it behind Stalin's statue. Both a de-politicizing description and the stone representations of the gulag stood together with the statue, epitomizing the tension over the Stalinist past.

Luzhkov's decision to erect a huge, 60-metrehigh statue of Peter the Great nearby more accurately indicated how many political elites preferred to remember the past-by skipping over the Soviet period entirely and glorifying Russia's Tsarist period (Figure 3). Although the city ostensibly held a public competition to design the monument, Luzhkov's favourite sculptor Zurab Tsereteli got the commission (Smith 2002). After the statue took up its dominating position on the Moscow skyline in 1997, two public groups spoke out against it. One group, a coalition of artists led by gallery owner Marat Gel'man, pressed for a public referendum on removing the statue. Luzhkov promised to create a commission to study the matter, but this proved to be merely a stalling tactic. As Smith (2002) notes, Tsereteli's supporters in the political and art worlds then carried out a massive campaign in the press to defend the sculpture and to publicize the reported \$12 million cost of dismantling it. The mayor's efforts to mobilize 'public opinion' paid off, with surveys revealing that only 12 per cent of Muscovites wanted to hold the 'costly' referendum, and, although many had reservations about the monument's aesthetic merits, a full 86 per cent spoke against dismantling it (Itar-Tass 1997). Armed with this data, the 


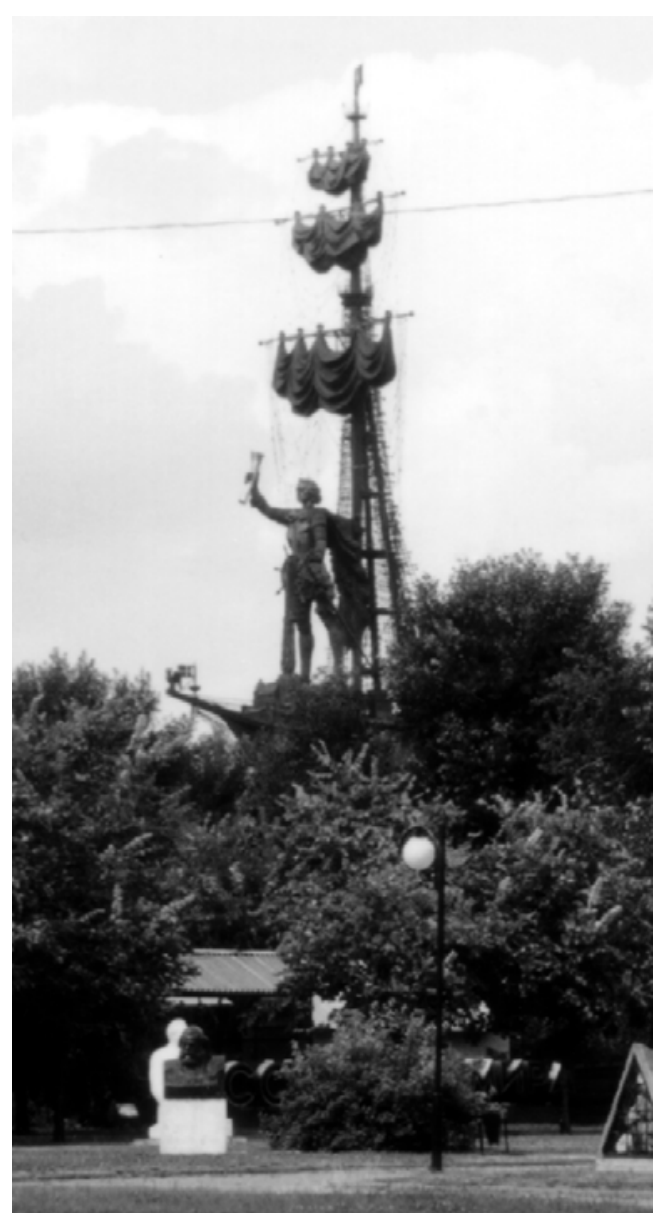

Figure 3 Peter the Great statue, Moscow, July 1999. The Park of Arts lies in the foreground.

Photograph by B. Forest and J. Johnson.

mayor's commission decided to leave the statue in place.

Not long after this decision, another group 'spoke out', but in a very different way. In July 1997, the obscure 'RSFSR Revolutionary Military Council' placed plastic explosives around the monument and threatened to blow it up in protest of Luzhkov's threats to remove Lenin's body from his mausoleum on Red Square. Although the group did not actually detonate the explosives, they declared the monument 'symbolically destroyed' (Kamakin 1997).

Thus, the transformation of the Park of Arts demonstrates how leading Russian politicians have often chosen to avoid confrontations with the totalitarian past. De-politicizing Soviet statues and icons through their placement in the park represented an attempt to circumvent the kind of vigorous, participatory debates characteristic of German public memory. The statues of Soviet leaders in the Park of Arts remained in their new places, silent witnesses to a past that many Russian elites and publics preferred not to remember. In addition, Luzhkov's decision to construct the widely detested Peter the Great statue illustrates how organized public groups have often been marginalized in the memorialization process. Although the statue faced challenges from public groups with very different compositions, ideologies and motivations, Luzhkov and his city government used their influence to marshal the support of broader 'public opinion' and justify the statue's presence. The statue remained despite its unpopularity, exemplified by an aborted attempt to blow it up-a far cry from the 'normal' process of negotiation in Germany.

\section{'Public' cultures of memory}

As Staeheli (1996) suggests, many scholars tend to assume that a 'public place' like a memorial can be equated with the 'public sphere'. Yet to do so fetishizes places of memory as objects rather than ongoing sets of processes through which understandings of political community and social identity are negotiated. Further, by mistaking the physical existence of 'public places' as evidence of a public sphere, scholars do not pay enough attention to the ways that 
place-making processes produce publics. The three case studies presented here indicate how public memory is a process, rather than material object or outcome. The comparison of German and Russian public memory since 1989 highlights the distinct ways in which multiple elites and publics typically engage in the memorialization process, illustrating why studies of public memory should move beyond the simple dichotomy between 'elite' and 'public'.

These examples also demonstrate the complex ways various 'publics' re-narrate national history(s) through place-making. Groups may have different agendas and conceptions that sometimes lead to elite-public conflicts, but that may also engender elite-elite and publicpublic conflicts. The category of 'counter-memory' as 'resistance' is too simplistic: a range of actors and groups may act in ways not necessarily structured by opposition to state or elite domination. Furthermore, civic organizations and interest groups may have highly differentiated access to public forums that affect their power and influence in the process of public memory.

Discussions and events about Sachsenhausen, for example, took place in a range of venues, including the local and national media, artistic practices, public competitions and protests. While these discussions were at times quite contentious, overall the process resulted in negotiation and the incorporation of different perspectives. Participants see the current proposal for Sachsenhausen's future development as a compromise solution that incorporates different layers of history, contemporary social views and Western humanitarian (or universalist) hopes for the future.

Moreover, given the complex histories and post-unification debates about Sachsenhausen, some Western museum memorial directors now argue that different claims to 'victim' status and social responsibility for past crimes should be evaluated by comparing different totalitarian periods within German history at particular historic sites. These same directors may not have supported such a process in the former West Germany in the 1980s because they may have interpreted the Kohl administration's cultural politics as an attempt to blur the categories of National Socialist victim and perpetrator (see Habermas 1989; Maier 1988; Till 1996). Sachsenhausen shows how GDR and even FRG approaches to representing and remembering totalitarian pasts can be reconceptualized.

In the new Germany, emerging practices of public memory may conflict with existing narratives, political cultures and social hierarchies that limit the participation and influence of some groups-notably former East German citizens-but there is still a sense that the 'normal' or proper process of memorialization involves vigorous public debates and negotiation rather than simple top-down, elitedriven decision-making. Civic organizations play a central role in these discussions and processes, and a broad array of publics successfully engaged 'official' memorial and planning proposals to produce new conceptions of German identity through a confrontation with the past.

In contrast, Russian civic organizations have been both less interested and less influential in publicly confronting the more troublesome aspects of the Soviet past. The relative lack of interest-with the notable exception of Memorial-reflects a broadly shared opinion that such 'reckoning with' or 'atoning for' the Soviet past is unnecessary for contemporary Russians and would devalue the more positive aspects of Soviet history. This indifference does not carry over into other realms of public memory, however. Peter the Great's immense and aesthetically questionable statue provoked intense outcry, both organized and diffuse. 
Similarly, civic and elite groups have co-operated to erect or restore many cultural and religious monuments across Russia.

More importantly, though, elites in local, provincial and federal governments have captured the memorialization process for those public sites with potential political resonance. This is not to say that powerful Russian politicians ignore popular opinion; indeed, they are attentive to the national 'visions' that public monuments convey, and manipulate such monuments in order to associate themselves with attractive symbols and to bolster their legitimacy. Rather, as the case studies illustrate, their control over the process contributes to circumscribing debate over and recognition of the more controversial aspects of Soviet history.

This comparative perspective in discussions of public memory highlights the shifting nature of inclusions and exclusions of various publics and sub-publics. Conflicts over memorialization in Germany since 1989 show how even a relatively open and participatory culture of public memory still privileges experts in ways that can exclude or diminish other perspectives. Russia demonstrates, however, that such exclusion is relative: post-totalitarian societies may develop a top-down rather than a more participatory culture of public memory, ultimately placing greater constraints on the ways in which a nation can imagine a new identity for itself.

\section{Acknowledgements}

The authors contributed equally to this article and are listed alphabetically. The Nelson A. Rockefeller Center at Dartmouth College, the Association of American Geographers (Anne U. White Grant), the Alexander von Humboldt Foundation and the Office of the Vice President for Research/Dean of the Graduate School (Grant in Aid) at the University of Minnesota provided research support for this article. We would like to give special thanks to Derek Alderman, Owen Dwyer and Steven Hoelscher for their help and encouragement, and for organizing this special issue. Thanks also to Rob Kitchin, David Sibley and two anonymous reviewers for their thoughtful comments on earlier versions of the article.

\section{Notes}

1 We use the term public memory to emphasize the complex interactions and tensions within and between elite and other social groups. The term public implies political engagement and discussion, whereas cultural memory need not be political (Sturken 1997).

2 See the voluminous literature about working through the past in Germany (Assmann and Frevert 1999; Jaspers 1961; Kittel 1993; Reichel 1995).

3 On hauntings, ghosts, memory and place, see Bell (1997), Gordon (1997), Pile (2002) and Till (forthcoming).

4 Information for this section comes from numerous personal interviews, newspaper articles and participantobservations collected and conducted by Till from 1995 to 2001. On the history of Sachsenhausen, see Endlich (1992), Morsch (1996), Till (forthcoming) and Wiedmer (1999).

5 Forty-one national associations exist for the pre-1945 prisoner groups; 17 are the most important numerically and have national Sachsenhausen committees. In Germany, three Sachsenhausen committees exist (West Berlin, East Germany and West Germany); other national associations include the Central Council of German Jews, the Central Council of Sinti and Roma, four homosexual organizations and the Social Democratic Working Group. The foreign groups, according to Morsch, are unified and have national groups with subgroups. The prisoner advisory board consists of representatives from up to twenty groups, including post-1945 groups (Till, personal interviews with Günter Morsch, Oranienburg, 1997).

6 Similar debates emerged for development proposals at Ravensbrück and Auschwitz (see Charlesworth 1994; Dwork and van Pelt 1996). 


\section{Benjamin Forest et al.}

7 Oranienburg gained a reputation for radical right activity after unification, and visitors to the camp were harassed by neo-Nazis, visitor books had anti-Semitic entries and the camp suffered physical defacements, including an arson attack on the so-called Jewish barracks in 1992 (Oranienburger Generalanzeiger 1995).

8 One recent exception to this trend was Moscow mayor Yurii Luzhkov's decision to abandon plans to build numerous monuments representing characters from Mikhail Bulgakov's novel Master and Margarita in the wealthy Patriarch's Pond area. The outcry among local residents was so great that Luzhkov scaled back the project considerably, agreeing to erect only a simple monument to Bulgakov himself (Balmforth 2003).

9 Support in Moscow itself was more mixed, with a VTsIOM poll showing 44 per cent in favour and 38 per cent opposed (Saradzhyan 2002).

10 Ironically, there is a memorial space at the former Gestapo Headquarters in central Berlin, called the Topography of Terror International Documentation Centre. In contrast, however, this space functions as an 'open wound' of the city and nation, rather than as a monument to Nazi officers and leaders (Till forthcoming).

\section{References}

Abdullaev, N. (2002) Notes from Moscow: the bronze Chekist, Transitions Online, Whttp://www.tol.cz/ look/TOLnew/article.tpl?IdLanguage LR \& IdPublication

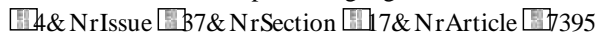
(accessed 1 October 2002).

Abu-Lughod, L. (1990) The romance of resistance, American Ethnologist 17: 41-55.

Agnew, J. (1998) The impossible capital: monumental Rome under liberal and fascist regimes, 1870-1943, Geografiska Annaler 80B: 229-240.

Aktives Museum (1990) Erhalten, Zerstören, Verändern: Denkmäler der DDR in Ost-Berlin: Eine dokumentarische Ausstellung. Berlin: Aktives Museum und Neue Gesellschaft für Bildende Kunst.

Andreeva, N. (1990 [1988]) I cannot give up my principles, 13 March, translated in The Current Digest of the Post-Soviet Press XL, p. 13.

Applebaum, A. (1997) A dearth of feeling, in Kimball, R. and Kramer, H. (eds) The Future of the European Past. Chicago: Ivan Dee, pp. 25-50.

Assmann, A. and Frevert, U. (1999) Geschichtsvergessenheit-Geschichtsvergessenheit: vom Umgang mit deutschen Vergangenheiten nach 1945. Stuttgart: Deutsche Verlags-Anstalt.
Associated Press (2002) Activists protest Dzerzhinsky statue plan, 17 Sept.

Atkinson, D. and Cosgrove, D. (1998) Urban rhetoric and embodied identities: city, nation, and empire at the Vittorio Emanuele II monument in Rome, 1870-1945, Annals of the Association of American Geographers 88: 28-49.

Azaryahu, M. (1997) German reunification and the politics of street names: the case of East Berlin, Political Geography 16: 479-493.

Bal, M., Crewe, J. and Spitzer, L. (eds) (1999) Acts of Memory: Cultural Recall in the Present. Hanover, NH: Dartmouth College, University Press of New England.

Balmforth, R. (2003) Moscow literary site saved after residents protest, Reuters, 1 April.

Barkan, E. (2000) The Guilt of Nations: Restitution and Negotiating Historical Injustices. New York: W.W. Norton.

Bell, M. (1997) The ghosts of place, Theory and Society 26: 813-836.

Berliner Morgenpost (1993) Wohnungsbau rund um das ehemalige KZ-Gelände, 17 Feb.: 1.

Birch, D. (2002) Russian nostalgia feeds struggle over monument to KGB founder, Baltimore Sun, 30 Nov.: $1 \mathrm{~A}$.

Boym, S. (2001) The Future of Nostal gia. New York: Basic Books.

Buruma, I. (1994) The Wages of Guilt: Memories of War in Germany and Japan. New York: Farrar, Straus, and Giroux.

Charlesworth, A. (1994) Contesting places of memory: the case of Auschwitz, Environment and Planning D: Society and Space 12: 579-593.

Cohen, S.F. (1985) Rethinking the Soviet Experience: Politics and History Snce 1917. New York: Oxford University Press.

Conquest, R. (1973) The Great Terror. New York: Macmillan.

Daniels, R.V. (1993) The End of the Communist Revolution. New York: Routledge.

Davis, N.Z. and Starn, R. (1989) Memory and Countermemory, Representations 26: Special Issue.

De Soto, H.G. (1996) (Re)inventing Berlin: dialectics of power, symbols and pasts, 1990-1995, City and Society 1: $29-49$.

Der Tagesspiegel (1993) Abreißen, Fluten oder als Mahnmal erhalten, 17 Feb.: 1.

Deutscher Bundestag (1994) Bericht der Enquete-Kommission: 'Aufarbeitung von Geschichte und Folgen der SED-Diktatur in Deutschland', gemäß Beschluß des Deutschen Bundestages vom 12. März 1992 und vom 20. Mai 1992. 
Deutscher Bundestag, 12. Wahlperiode, Referat Öffentlichkeitsarbeit.

Dodds, D. and Allen-Tompson, P. (eds) (1994) The Wall in My Backyard: East German Women in Transition. Amherst: University of Masschusetts Press.

Dwork, D. and van Pelt, R.J. (1996) Auschwitz, 1270 to the Present. New York: Norton.

Endlich, S. (ed.) (1992) Brandenburgische Gedenkstätten für die Verfolgten des NSRegimes: Perspektive, Kontroversen und internationale Vergleiche. Berlin: Edition Hentrich.

Filimonova, A. (2002) 'Zheleznyi Feliks' mozhet vernut’sia na Lubianku, Izvestiia, 13 Sept.: 21.

Forest, B. and Johnson, J.E. (2002) Unraveling the threads of history: Soviet-era monuments and post-Soviet national identity in Moscow, Annals of the Association of American Geographers 92: 524-547.

Forschungsgruppe StadtDorf and Schäfer, R. (1994) Prozessorientierte Stadtentwicklungsplanung Oranienburg: 'Umgang mit der NSVergangenheit:' 2. Forum Stadtentwicklung Oranienburg am 6.12.1994 in Schloss Oranienburg: Protokoll. Oranienburg: Stadt Oranienburg.

Foucault, M. (1977a) Discipline and Punish: The Birth of the Prison. New York: Pantheon Books.

Foucault, M. (1977b) Language, Counter-memory, Practice. Ithaca, NY: Cornell University Press.

Foucault, M. (1980) Power/Knowledge. New York: Pantheon.

Fraser, N. (1990) Rethinking the public sphere: a contribution to the critique of actually existing democracy, Social Text 25/26: 56-80.

Frazier, L.J. (1999) 'Subverted memories': countermourning as political action in Chile, in Bal, M., Crewe, J. and Spitzer, L. (eds) Acts of Memory: Cultural Recall in the Present. Hanover, NH: Dartmouth College, University Press of New England, pp. 105-119.

Fulbrook, M. (1997) Reckoning with the past: heroes, victims and villains in the history of the GDR, in Monteath, P. and Alter, R. (eds) Rewriting the German Past: History and Identity in the New Germany. Atlantic Highlands, NJ: Humanities Press, pp. 175-196.

Fulbrook, M. (1999) German National Identity After the Holocaust. Cambridge: Polity Press.

Gillis, J. (ed.) (1994a) Commemorations: The Politics of National Identity. Princeton, NJ: Princeton University Press.

Gillis, J. (1994b) Memory and identity: the history of a relationship, in Gillis, J. (ed.) Commemorations: The Politics of National Identity. Princeton, NJ: Princeton University Press, pp. 3-26.
Gordon, A. (1997) Ghostly Matters: Haunting and the Sociological Imagination. Minneapolis: University of Minnesota Press.

Habermas, J. (1989) The New Conservativism: Cultural Criticism and the Historians' Debate. Cambridge, MA: MIT Press.

Habermas, J. (1997) A Berlin Republic: Writings on Germany. Lincoln: University of Nebraska Press.

Halbwachs, M. (1992 [1941, 1952]) On Collective Memory. Chicago: University of Chicago Press.

Herf, J. (1997) Divided Memory: The Nazi Past in the Two Germanys. Cambridge, MA and London: Harvard University Press.

Hershkovitz, L. (1993) Tiananmen-Square and the politics of place, Political Geography 12: 395-420.

Hobsbawm, E. and Ranger, T. (1992) The Invention of Tradition. Cambridge and New York: Cambridge University Press.

Hörschelmann, K. (2001) Breaking ground: marginality and resistance in (post) unification Germany, Political Ge ography 20: 981-1004.

Huyssen, A. (1997) The voids of Berlin, Critical Inquiry 24: 57-81.

Itar-Tass (1997) Monument to Peter will remain in place, Nezavisimaia gazeta, 20 May: 2.

Jaspers, K. (1961) The Question of German Guilt. New York: Capricorn Books.

Johnson, N. (1999) The spectacle of memory: Ireland's remembrance of the Great War, 1919, Journal of Historical Geography 25: 36-56.

Kamakin, A. (1997) Terrorism, Nezavisimaia gazeta, 8 July: 2.

Khrushchev, N. (1956) The Crimes of the Stalin Era: Special Report to the 20th Congress of the Communist Party of the Soviet Union. New York: New Leader.

Kittel, M. (1993) Die Legende von der 'Zweiten Schuld': Vergangenheitsbewältigung in der Ära Adenauer. Berlin: Ullstein.

Knight, A. (1988) The KGB, Police and Politics in the Soviet Union. Boston, MA: Unwin Hyman.

Koonz, C. (1994) Between memory and oblivion: concentration camps in German memory, in Gillis, J. (ed.) Commemorations: The Politics of National Identity. Princeton, NJ: Princeton University Press, pp. 258-280.

Kramer, M. (2001) Why Soviet history matters in Russia, PONARS Policy Memo 183. Center for Strategic and International Studies, 耳http://www.csis.org/ruseura/ PONARS/policymemos/pm_0183.pdf uary 2004)

Kurilla, I. (2002) Who is at the gate? The symbolic battle of Stalingrad in contemporary Russia, PONARS Policy 


\section{Benjamin Forest et al.}

Memo 268. Center for Strategic and International Studies, [Dhttp://www.csis.org/ruseura/PONARS/policymemos/pm_0268.pdf [i: (accessed 3 January 2004).

LaCapra, D. (1994) Representing the Holocaust: History, Theory, Trauma. Ithaca, NY and London: Cornell University Press.

Legg, S. (2004) Contesting and Surviving Memory: Space, Nation and Nostalgia in Les Lieux de Mémoire, paper, Looking Back at Nora conference, Institute of Romance Studies, London, February.

Ley, D. and Olds, K. (1988) Landscape as spectacle: worlds fairs and the culture of heroic consumption, Environment and Planning D: Society \& Space 6: 191-212.

Libeskind, D. (1993) Mourning (conceptual proposal for Oranienburg public art competition), 12 February.

Ligachev, E. (1993) Inside Gorbachev's Kremlin. New York: Pantheon Books.

Luzhkov, Y. (1996) My Deti Tvoi, Moskva. Moscow: Bagrius.

Maier, C.S. (1988) The Unmasterable Past: History, Holocaust, and German National Identity. Cambridge, MA: Harvard University Press.

Marcuse, H. (2001) Legacies of Dachau. Cambridge: Cambridge Univeristy Press.

McAdams, A.J. (2001) Judging the Past in Unified Germany. Cambridge and New York: Cambridge University Press.

McDowell, L. (1999) Gender, Identity and Place: Understanding Feminist Geographies. Minneapolis: University of Minnesota Press.

Memorial (2002) Eshe raz o pamiatnike predsedateliu VChK-OGPU Dzerzhinskomu, एWhttp://www.memo. ruiㅐ (accessed 30 September 2002).

Morsch, G. (ed.) (1996) Von der Erinnerung zum Monument: Die Entstehungsgeschichte der Nationalen Mahn- und Gedenkstätte Sachsenhausen. Oranienburg: Stiftung Brandenburgische Gedenkstätten und Edition Hentrich.

Morsch, G. (2001) Concentration camp memorials in eastern Germany since 1989, in Roth, J. and Maxwell-Meynard, E. (eds) Remembering for the Future: The Holocaust in an Age of Genocides. New York: Palgrave, pp. 367-382.

Nevins, J. (2003) Restitution over coffee: truth, reconciliation, and environmental violence in East Timor, Political Geography 22: 677-701.

Nora, P. (1989) Between memory and history: les lieux de mémoire, Representations 26: 7-25.

Nora, P. (1996) Realms of Memory: Rethinking the French Past, Vol. 1: Conflicts and Divisions. New York: Columbia University Press.
O’Flynn, K. (2003) City rejects return of Dzerzhinsky, Moscow Times, 22 Jan.: 3.

Oranienburger Generalanzeiger (1995) Chronik der Ereignisse seit September 1992, 30 March.

Pile, S. (1997) Introduction: opposition, political identities and spaces of resistance, in Pile, S. and Keith, M. (eds) Geographies of Resistance. London: Routledge, pp. 132.

Pile, S. (2002) Spectral cities: where the repressed returns and other short stories, in Hillier, J. and Rooksby, E. (eds) Habitus: A Sense of Place. Aldershot: Ashgate, pp. 219-239.

Public Opinion Foundation (2002) Zagolovok: Vokrug pamiatnika F. Dzerzhinskomu, Whttp://www.fom.ru (accessed 28 September 2002).

Reichel, P. (1995) Politik mit der Erinnerung: Gedäcthnisorte im Streit um die Nationalsozialistische Vergangenheit. Munich: Hanser.

Rodin, I. (2002) Russia debates restoring KGB 'Iron Felix' statue, Reuters, 27 Sept.: 3.

Rose, R. (2002) A Decade of New Russia Barometer Surveys. Glasgow: Centre for Public Policy, University of Strathclyde.

Rürup, R. (2003) Netzwerk der Erinnerung: 10 Jahre Gedenkstättenreferat der Siftung Topographie des Terrors. Berlin: Stiftung Topographie des Terrors.

Saradzhyan, S. (2002) Iron Felix panned by Kremlin, Patriarch, Moscow Times, 23 Sept.: 3.

Scott, J.C. (1985) Weapons of the Weak: Everyday Forms of Peasant Resistance. New Haven, CT and London: Yale University Press.

Sharp, J., Routledge, P., Philo, C. and Paddison, R. (2000) Entanglements of power: geographies of domination/resistance, in Sharp, J., Routledge, P., Philo, C. and Paddison, R. (eds) Entanglements of Power: Geographies of Domination/Resistance. Routledge, London and New York, pp. 1-42.

Smith, F. (2000) The neighbourhood as site for contesting German reunification, in Sharp, J., Routledge, P., Philo, C. and Paddison, R. (eds) Entanglements of Power: Geographies of Domination/Resistance. London and New York: Routledge, pp. 122-147.

Smith, K.E. (1996) Remembering Stalin's Victims: Popular Memory and the End of the USSR. Ithaca, NY: Cornell University Press.

Smith, K.E. (2002) Mythmaking in the New Russia: Politics and Memory During the Yeltsin Era. Ithaca, NY: Cornell University Press.

Stadt Oranienburg (1992) Gutachterverfahren: Urbanisierung des ehemaligen Geländes der SSKaserne Oranienburg. Oranienburg: Stadt Oranienburg. 
Stadt Oranienburg (1993) Gutachterverfahren: Urbanisierung des ehemaligen Geländes der SSKaserne Oranienburg: Dokumentation. Stadt Orienburg in Zusammenarbeit mit der Landesentwicklungsgesellschaft für Städtebau Wohnen und Verkehr des Landes Brandenburg GmbH. Oranienburg: Stadt Oranienburg.

Staeheli, L.A. (1996) Publicity, privacy, and women's political action, Environment and Planning D: Society \& Space 14: 601-619.

Staeheli, L.A. (1997) Citizenship, community, and struggles for public space, The Professional Geographer 49: 28-38.

Sturken, M. (1997) Tangled Memories: The Vietnam War, the AIDS Epidemic, and the Politics of Remembering. Berkeley: University of California Press.

Suny, R. (1999) Provisional stabilities: the politics of identities in post-Soviet Eurasia, International Security 24: 139-178.

Thomas, M. (2002) Out of control: emergent cultural landscapes and political change in urban Vietnam, Urban Studies 39: 1611-1624.

Till, K.E. (1996) Place and the politics of memory: a geo-ethnography of memorials and museums in Berlin, $\mathrm{PhD}$ dissertation, Department of Geography, University of Wisconsin.

Till, K.E. (1999) Staging the past: landscape designs, cultural identity and Erinnerungspolitik at Berlin's Neue Wache, Ecumene 6: 251-283.

Till, K.E. (2003) Places of memory, in Agnew, J., Mitchell, K. and Ó'Tuathail, G. (eds) Companion to Political Geography. Oxford: Blackwell, pp. 289-301.

Till, K.E. (2005) The New Berlin: Memory, Politics, Place. Minneapolis: University of Minnesota Press (forthcoming).

Tolstikhina, A. (1998) They're ready for restoration: State Duma moves to return Iron Felix to his pedestal, Segodnia, 3 Dec.: 1 , 6.

Traynor, I. (2000) Capital letters: Russia's new strongman puts Stalin back on a pedestal, The Guardian, 13 May: 14.

Tucker, R. (1990) Stalin in Power: The Revolution from Above, 1928-1941. New York: W.W. Norton.

Tumarkin, N. (1994) The Living and the Dead: The Rise and Fall of the Cult of World War II in Russia. New York: Basic Books.

Uzelac, A. (2000) No Lubianka return for KGB founder, Moscow Times, 8 July: 3.

VTsIOM Analytic Agency (2003) VTsIOM Nationwide Survey, February 28-March 3, 2003, Whttp:// www.russiavotes.org/Mood_rus_cur.htm\#395 [0] (accessed 11 January 2004).

Weir, F. (2002) Wary of its past, Russia ignores mass grave site, Christian Science Monitor, 10 Oct.: 1.
Wiedmer, C.A. (1999) The Claims of Memory: Representations of the Holocaust in Contemporary Germany and France. Ithaca, NY and London: Cornell University Press.

Yablokova, O. and Valueva, Y. (2003) Tears and red roses outside the theater, Moscow Times, 24 Oct.: 1.

Young, J. (1993) The Texture of Memory: Holocaust Memorials and M eaning. New Haven, CT: Yale University Press.

\section{Abstract translations}

\section{L'identité nationale post-totalitaire: le sou- venir public en Allemagne et en Russie}

Par une analyse comparative de l'Allemagne et de la Russie, cet article explore comment la participation dans le processus de commémoration peut intervenir et trouver son expression dans la constitution d'une identité nationale de sociétés post-totalitaires. Compte tenu que leurs identités nationales étaient liées de près à des régimes tyranniques, les sociétés post-totalitaires se confrontent aujourd'hui au problème familier de se re-présenter un portrait national civique et démocratique. Nous mettons en comparaison trois lieux de commémoration: le monument commémoratif du camp de concentration de Sachsenhausen en Allemagne, et le Carré Lubianka et le Parc des Arts en Russie. Nous soutenons que même si le pouvoir de l'État a été réduit de manière dramatique et que la société civile a émergé, un modèle dichotomique simple opposant l'élite au public ne permet pas de comprendre la nature de la participation dans le processus de la reconstitution du souvenir. Plutôt, des interactions mutuelles entre une multitude de publics et d'élites, se distinguant à travers divers contextes par type et par intensité, se combinent en un pastiche complexe du souvenir public qui permet à la fois d'interpréter le passé d'une nation et de préconiser des modèles séduisants axés 
RDA illustre comment les débats passablement ouverts peuvent exclure certaines représentations de la nation. Néanmoins, des débats publics assez vigoureux ont été tenus en Allemagne sur la commémoration des époques totalitaires qui l'ont marquée. Le cas de la Russie fait contraste. Les groupes d'élites ont le plus souvent neutralisé ou embrouillé la participation au processus de commémoration. Ils sont peu disposés à reconnaître le passé totalitaire du pays et répugne à l'identité nationale en émergence qui est moins civique et démocratique qu'en Allemagne.

Mots-clefs: Allemagne, monuments commémoratifs, souvenir public, Russie.

\section{Identidad nacional en las sociedades posto- talitarias: la memoria pública en Alemania y Rusia}

Por un análisis comaprativo de Alemania y Rusia este papel explora cómo participación en el proceso de memorializar afecta y refleja la formación de identidad nacional en las sociedades postotalitarias. Estas sociedades postotalitarias se enfrentan al problema común de cómo re-presentar su carácter nacional como cívico y democrático, pues sus identidades nacionales han estado estrechamente ligadas con régimenes opresivas. Por un estudio compara- tivo de tres sitios de memoriales-el memorial del campo de concentración de Sachsenhausen en Alemania, la Plaza Lubianka y el Parque de Artes en Rusia, sugerimos que aún cuando se reduce dramáticamente el poder del estado y se abre la sociedad civil—un simple dicotomía elite-público no capta adecuadamente la naturaleza de participación en el proceso de re-formación de la memoria. Más bien, interacciones mutuas entre múltiples elites y públicos, de varios tipos e intensidades a través de contextos, se combinan a formar un pastiche complejo de memoria pública que tanto interpreta el pasado de una nación como sugiere modelos deseables para su futuro. La dominación de un estilo occidental de memorializar en el antiguo Alemania Oriental demuestra como hasta los debates relativamente abiertos pueden excluir a ciertas representaciones de la nación. No obstante, en Alemania han habido debates públicos comparativamente enérgicos sobre cómo memorializar sus períodos totalitarios. Por contraste, grupos élites rusos han burlado o manipulado participación en el proceso de memorializar, lo cual refleja tanto una reticencia a tratar su pasado totalitario como una identidad nacional emergente menos cívica y menos democrática que la de Alemania.

Palabras claves: Alemania, monumentos y memorials, la política de memoria, memoria pública, Rusia. 